\title{
A new triterpenic diester from the aerial parts of
}

\section{Chrysanthemum macrocarpum}

Naima Boutaghane, ${ }^{\mathrm{a}, \mathrm{b}}$ Laurence Voutquenne -Nazabadioko, ${ }^{* a}$ Alain Simon ${ }^{\mathrm{c}}$, Dominique Harakat $^{\mathrm{d}}$, Kaddour Benlabed ${ }^{\mathrm{e}}$, Zahia Kabouche $^{\mathrm{b}}$

${ }^{\mathrm{a}}$ Groupe Isolement et Structure, Institut de Chimie Moléculaire de Reims (ICMR), CNRS UMR 7312, UFR de Pharmacie, BP 1039, 51687 Reims; France.

bLaboratoire d'Obtention des Substances Thérapeutiques, Faculté des Sciences Exactes, Université de Constantine 1, Chaabet Ersas Campus, 25000 Constantine, Algeria.

${ }^{\mathrm{c}}$ Laboratoire de Chimie Physique Minérale, UPRES EA-1085, Biomolécules et cibles cellulaires tumorales, Faculté de Pharmacie, 2 rue du Dr. Marcland, 87025 Limoges Cedex, France.

${ }^{d}$ Service Commun d'Analyses, Institut de Chimie Moléculaire de Reims (ICMR), CNRS UMR 7312, Bat. 18 B.P.1039, 51687 Reims Cedex2, France

${ }^{e}$ Laboratoire de Microbiologie. CHU Ben Badis, Constantine, Algeria.

* Corresponding author. Tel.: +33 326918209 ; Fax : + 33326913166.

E-mail adress :laurence.nazabadioko@univ-reims.fr (L. Voutquenne-Nazabadioko) 


\begin{abstract}
A new triterpenic diester, 3,21-dipalmitoyloxy-16 $\beta, 21 \alpha$-dihydroxy- $\beta$-amyrine(1), along with two natural cyclitols, conduritol C (2) and viburnitol (3), four known triterpenes (4-7), and seven known flavonoids (8-14) were isolated from the aerial parts of Chrysanthemum macrocarpum. Their structures were established on the basis of extensive 1D and 2D NMR $\left({ }^{1} \mathrm{H},{ }^{13} \mathrm{C}, \mathrm{COSY}, \mathrm{HMBC}, \mathrm{HSQC}\right.$, and ROESY) and ESIMS studies. The chloroform fraction, taraxasterol (4) and $\beta$-sitosterol (7) were investigated for their antibacterial activity against Staphylococcus aureus, Enterococcus faecalis, Escherichia coli, Pseudomonas aeruginosa and Klebsiella pneumoniae. The chloroform fraction and taraxasterol (4) showed a weak antibacterial activity and were evaluated for their cytotoxic activity against human colon cancer HT-29 cells and human prostate carcinoma PC3 cells. The results indicated that both the chloroform fraction and taraxasterol (4) inhibited cell proliferation of both PC3 and HT-29 cells.
\end{abstract}

\title{
Keywords:
}

Chrysanthemum macrocarpum, Asteraceae, Triterpenic diester, Cyclitol, NMR, Antibacterial activity 


\section{Introduction}

The Chrysanthemum genus (Asteraceae) is found world-wide and some species have been extensively used as food additives or in traditional medicine to treat inflammation, headache, ulcerative colitis, vertigo, eye irritation, hypertension, and respiratory diseases (Jiangsu, 1993; Yang et al., 2000; Yoshikawa et al., 2000; Matsuda et al., 2002). A series of recent studies have suggested that the Chrysanthemum genus possesses a strong anti-cancer and anti-human immunodeficiency virus type 1 (HIV-1) activity. (Ukiya et al., 2002; Lee et al., 2003), Anti-inflammatory (Cheon et al., 2009), antinociceptive (Shi et al., 2011) as well as anti-oxidant activities (Yan et al., 1999) have been also confirmed. The phytochemical profile of Chrysanthemum species has shown the presence of terpenoids (Ukiya et al., 2001), flavonoids and phenolic compounds (Lin and Harnyl, 2010). Fifteen Chrysanthemum species grow in Algeria (Quezeland Santa, 1963).Chrysanthemum macrocarpum (Sch.Bip.)Coss.\&Kralik ex Batt., a synonym of Endopappus macrocarpus (Coss. \& Kralik ex Batt. \& Trabut) Sch.Bip., is an endemic species used in traditional medicine as a scabicide and to treat intestinal infections. Touareg people also use this species in food for flavouring and as an herbal tea (Boukef, 1986; Bellakhdar, 1997). We have previously analyzed the chemical composition of the essential oil of this species (Boutaghane et al., 2008). This paper reports the isolation and structural elucidation of one new triterpene fatty acid diester (1) and two natural cyclitols, in addition to four known triterpenes, and seven known flavonoids from the aerial parts of C. macrocarpum (Fig. 1). The antibacterial activity and cytotoxic activity against HT-29 and PC3 cells of the chloroform soluble fraction and taraxasterol (4) were also evaluated in order to obtain an insight into the beneficial effects of this plant species. 


\section{Results and discussion}

The aerial parts of $C$. macrocarpum were extracted with $20 \%$ aq. $\mathrm{MeOH}$. After $\mathrm{MeOH}$ removal, the crude extract in $\mathrm{H}_{2} \mathrm{O}$ was successively partitioned with $\mathrm{CHCl}_{3}$, EtOAc, and $n$ - $\mathrm{BuOH}$. The $\mathrm{CHCl}_{3}$ soluble fraction was purified by chromatographic separations over silica gel, yielding the new triterpene fatty ester (1) and the known compounds identified as taraxasterol (4) (Reynolds et al., 1985), stigmasterol (6), $\beta$-sitosterol (7) (Kojima et al., 1990), and calenduladiol-3-O-myristate (5) (Ukiya et al., 2001) (Fig. 1). The purification of the EtOAc soluble fraction gave the natural cyclitolsconduritol $\mathrm{C}$ (2)(Hiroki et al., 1998) and viburnitol (3) (Kindl et al., 1966) along with seven known flavonoids: apigenin (8), 7-O-methylapigenin (9), apigenin-7-O-glucoside (10) (Bennini et al., 1992), kaempferol-3-O-glucoside (11), kaempferol-7-O-glucoside (12) (Kim et al., 2005), luteolin-3'-O-glucoside (13) (Moiteiro et al., 2008) and 6- $C$-glucosyl-8-Carabinosylapigenin (14) (Krafczyk et al., 2008). Their structures were elucidated using chemical and spectroscopic methods including 1D and 2D NMR experiments, and ESIMS.

\subsection{Structure elucidation of compounds 1-3}

Compound 1 was obtained as a viscous liquid. The HRESIMS (positive ion mode) exhibited a quasimolecular ion peak at $\mathrm{m} / \mathrm{z} 957.8634[\mathrm{M}+\mathrm{Na}]^{+}$(calc. for $\mathrm{C}_{62} \mathrm{H}_{110} \mathrm{O}_{5} \mathrm{Na}$, 957.8653) suggesting a molecular formula of $\mathrm{C}_{62} \mathrm{H}_{110} \mathrm{O}_{5}$. The positive ESIMS spectrum gave the same pseudomolecular ion peak at $\mathrm{m} / \mathrm{z} 957[\mathrm{M}+\mathrm{Na}]^{+}$with a ion fragment observed at $m / z, 701\left[\mathrm{M}+\mathrm{Na}-\mathrm{C}_{16} \mathrm{H}_{32} \mathrm{O}_{2}\right]^{+}$in agreement with the loss of a palmitoyloxy side chain. The presence of two acyloxy groups in compound $\mathbf{1}$ was supported by the presence in the ${ }^{13} \mathrm{C}$ NMR spectrum of two carbonyl signals at $\delta_{\mathrm{C}} 173.3$ and 173.7 and in the ${ }^{1} \mathrm{H}$ NMR spectra of signals due to two methylene groups bearing a carbonyl group at $\delta_{\mathrm{H}} 2.32\left(\mathrm{q}^{\mathrm{t}} \mathrm{d}, J=7.1,1.0 \mathrm{~Hz}, \mathrm{H}-2^{\prime}\right)$ and $2.36\left(\mathrm{q}^{\mathrm{t}} \mathrm{d}, J=7.7,2.7 \mathrm{~Hz}, \mathrm{H}-2^{\prime \prime}\right)$, and for two 
terminal methyl groups at $\delta_{\mathrm{H}} 0.90\left(6 \mathrm{H}, \mathrm{t}, J=7.4 \mathrm{~Hz}, \mathrm{H}-16^{\prime}\right.$ and $\left.\mathrm{H}-16^{\prime \prime}\right)$. The ${ }^{1} \mathrm{H}$ NMR spectra of 1 showed the presence of eight methyl singlets at $\delta 0.81,0.88,0.89,0.91$, $1.00,1.01,1.02$ and 1.27, an olefinic proton at $\delta 5.33(\mathrm{t}, J=3.5 \mathrm{~Hz}, \mathrm{H}-12)$, three methine protons bearing an oxygen at $\delta 4.43(\mathrm{dd}, J=11.7,4.7 \mathrm{~Hz}, \mathrm{H}-16), 4.53(\mathrm{dd}, J=9.3,5.5$ Hz, H-3) and 4.73 (brt, $J=3.4 \mathrm{~Hz}, \mathrm{H}-21$ ) (Table 1). The basic $\Delta^{12}$ oleanene skeleton (Mahato and Kundu, 1994) in 1 was supported by the following key HMBC correlations H-3/C-2, C-4, C-5, C-23, C-24; H-12/C-9, C-11, C-13, C-14, C-18; H-16/C-14, C-15, C-17, C-18, C-28; H-21/C-17, C-19, C-20, C-22, C-29, and C-30. The small coupling constant of H-21 (brt, $J=3.4 \mathrm{~Hz}, \mathrm{H}-21$ ) indicated an $\alpha$-axial position for the hydroxyl group, and the large coupling constants of H-16 $(J=11.7 \mathrm{~Hz})$ and H-3 $(J=9.3 \mathrm{~Hz})$, indicated a $\beta$-equatorial position for the hydroxyl groups. In the ROESY experiment, the interaction observed between $\mathrm{H}-18 / \mathrm{H}-30$ and between $\mathrm{H}-21 / \mathrm{H}-30$ confirmed the $\beta$ equatorial position for H-21.The $\alpha$-axial orientation of $\mathrm{H}-3$ and $\mathrm{H}-16$ was also confirmed by the ROEs observed between H-3 and H-5 $\alpha$ and H-23 $\alpha$, while H-16 showed a ROE correlation with H-27a. Thus, the aglycone of compound $\mathbf{1}$ was determined to be $3 \beta, 16 \beta, 21 \alpha$-trihydroxy-olean-12 ene. The downfield shifts of $\mathrm{H}-3$ and $\mathrm{H}-21$ at $\delta_{\mathrm{H}} 4.53$ and 4.73 , respectively in 1 suggested the esterification of the secondary hydroxyl groups at C-3 and C-21 by two acyloxy groups. This was confirmed by the HMBC correlations observed between $\mathrm{H}-3\left(\delta_{\mathrm{H}} 4.53\right)$ and the carbonyl carbon signal of the first acyloxy side chain $\left(\delta_{C} 173.7\right)$, and between $\mathrm{H}-21\left(\delta_{\mathrm{H}} 4.73\right)$ and the second carbonyl carbon signal $\left(\delta_{\mathrm{C}} 173.3\right)$. The two acyloxy groups were identified by ESIMS as being palmitic acid esters. Subtraction of the triterpene unit from the molecular formula of the ion fragment at $m / z, 701\left[\mathrm{M}+\mathrm{Na}-\mathrm{C}_{16} \mathrm{H}_{32} \mathrm{O}_{2}\right]^{+}$indicated that the second fatty acid ester was identical and correspond to a palmitic acid. Another ion fragment observed at $m / z, 685\left[\mathrm{M}+\mathrm{Na}-\mathrm{HO}-\mathrm{C}_{16} \mathrm{H}_{32} \mathrm{O}_{2}\right]^{+}$indicated the simultaneously loss of the 
palmitic acid in $\mathrm{C}-21$ position and $\mathrm{OH}$ in $\mathrm{C}-16$ position. Thus, compound $\mathbf{1}$ was identified as 3,21-dipalmitoyloxy-16 $\beta, 21 \alpha$-dihydroxy- $\beta$-amyrine.

Compound 2 was obtained as colourless crystals and afforded a $[\mathrm{M}+\mathrm{Na}]^{+}$ quasimolecular ion peak at $m / z, 169$ suggesting the molecular formula of $\mathrm{C}_{6} \mathrm{H}_{10} \mathrm{O}_{4} \mathrm{Na}$. In the ${ }^{13} \mathrm{C}$ NMR spectrum, six carbon signals were observed at $\delta_{\mathrm{C}} 66.6,71.2,72.4,72.5$, 126.6 and 132.4, and the corresponding ${ }^{1} \mathrm{H}$ signals were observed at $\delta_{\mathrm{H}} 3.95,3.64,4.20$, 3.43, 5.83 and 5.75, respectively (Table 2). The ${ }^{1} \mathrm{H}-{ }^{1} \mathrm{H}$ COSY spectrum of 2 showed a cyclic spin system with correlations observed between the olefinic protons at $\delta_{\mathrm{H}} 5.75$ and $\delta_{\mathrm{H}} 5.83$ and both protons $\mathrm{H}-4\left(\delta_{\mathrm{H}} 4.20\right)$ and $\mathrm{H}-1\left(\delta_{\mathrm{H}} 3.95\right)$. H-4 and $\mathrm{H}-1$ were also correlated with $\mathrm{H}-3\left(\delta_{\mathrm{H}} 3.43\right)$ and $\mathrm{H}-2\left(\delta_{\mathrm{H}} 3.64\right)$, respectively, and $\mathrm{H}-2$ with $\mathrm{H}-3$, suggesting a cyclohexenetetraol. In the HMBC spectrum $\mathrm{H}-4$ and $\mathrm{H}-1$ correlated with $\mathrm{C}$ 5 and C-6 indicating that the double bond was located in the C-5 (6) positions. The small coupling constant of $\mathrm{H}-4(\mathrm{t}, J=4.5 \mathrm{~Hz})$ indicate an $\alpha$-configuration of the hydroxyl group. The large coupling constants up to $7 \mathrm{~Hz}$ for protons $\mathrm{H}-1, \mathrm{H}-2$ and $\mathrm{H}-3$ indicate a $\beta$-configuration for the three hydroxyl groups in these positions. Therefore, 2 was deduced as being cyclohex-5-ene $1 \beta, 2 \beta, 3 \beta, 4 \alpha$-tetraol, also named conduritol $\mathrm{C}$ previously obtained by synthesis (Balci et al., 1990). To our knowledge, this is the first time that this compound has been isolated in a natural product.

Compound 3 displayed a quasi-molecular ion peak at $\mathrm{m} / \mathrm{z}, 187[\mathrm{M}+\mathrm{Na}]^{+}$indicating a molecular weight of 164 which is 18 mass units greater than that of $\mathbf{2}$ and suggesting a molecular formula of $\mathrm{C}_{6} \mathrm{H}_{12} \mathrm{O}_{5}$. Careful comparison of the NMR spectroscopic data of $\mathbf{3}$ with that of 2 (Table 2) showed in the ${ }^{1} \mathrm{H}$ and ${ }^{13} \mathrm{C}$ NMR signals of $\mathbf{3}$, the absence of the two olefinic carbon signals at $\delta_{\mathrm{C}} 126.6$ and 132.4 and the occurrence of hydroxyl group $\left(\delta_{\mathrm{H}} 4.02 / \delta_{\mathrm{C}} 69.6\right)$ and methylene carbon at $\delta_{\mathrm{C}} 37.1$. Full examination of the $2 \mathrm{D}$ NMR 
spectroscopic data further confirmed the structure of compound $\mathbf{3}$ as cyclohexa$1 \beta, 2 \alpha, 3 \beta, 4 \alpha, 5 \alpha-$ pentaol also named viburnitol (Kindl, H., et al., 1969).

\subsection{Antibacterial and cytotoxic activities}

The antibacterial activity of the $\mathrm{CHCl}_{3}$ soluble fraction, EtOAc soluble fraction, $n$ $\mathrm{BuOH}$ soluble fraction, and compounds $\mathbf{4}$ and $\mathbf{7}$ was performed using the disc diffusion method against two Gram-positive (S. aureus and E. faecalis) and three Gram-negative (E. coli, P. aeruginosa, K.pneumoniae) bacteria (Table 3). The chloroform fraction and 4 and 7 were further analyzed by TLC-direct bioautography on silica gel $\mathrm{GF}_{254}$ to determine the number of active compounds. As observed with the disc diffusion method, the assayfor bioautography demonstrated weak inhibition zones of chloroform fraction and taraxasterol (4) against the growth of Gram-negative (E. coli, $P$. aeruginosa, K.pneumoniae) bacteria. The clear zones were located separately on TLC suggesting that more than one compounds at different $R_{f}$ values involved in antibacterial effects. Nevertheless, no inhibition zone was observed with compound $\mathbf{7}$ at the concentration tested. Minimum inhibitory concentration (MICs) determination was performed by the serial dilution method (Table 3), ampicillin was used as a positive control in these tests. Only the $\mathrm{CHCl}_{3}$ fractionof $C$. macrocarpum notably inhibited the growth of all the tested bacteria (Gram-positive and Gram negative), and was shown to possess the strongest antibacterial activity against Gram negative with the largest inhibition zones (30 and $24 \mathrm{~mm}$ for $P$. aeruginosa and E. coli, respectively) and lowest MICs 0.5 to $8 \mu \mathrm{g} / \mathrm{ml}$.Compound 4 also showed relatively modest activity, most particularly against Gram negative bacteria K. pneumonia $(32 \mu \mathrm{g} / \mathrm{ml})$, E. Coli $(32$ $\mu \mathrm{g} / \mathrm{ml})$ and $P$. aeruginosa $(16 \mu \mathrm{g} / \mathrm{ml})$.Previous findings have shown that taraxasterol exhibited antibacterial properties (Singh et al., 2002; Singh and Dubey, 2001; Villarreal et al., 1994; Dai et al., 2001). The antibacterial activity of the chloroform fraction could, 
in part, be associated with the triterpenes such as taraxasterol (4), the main component of the chloroform fraction. In fact, it was also possible that the components in lower percentage might be involved in some type of synergism with the other active compounds. Our results support the use of $C$. macrocarpum in traditional medicine for diseases caused by infective agents.

To determine the cytotoxicity of the chloroform soluble fraction of $C$. macrocarpum and taraxasterol (4), cell proliferation was evaluated by MTT assay on two cell lines, the human HT-29 colorectal cancer cell line and the human PC3 prostate cancer cell line. The chloroform fraction and taraxasterol inhibited cell proliferation of both HT-29 and PC3 cancer cells in a dose- and time-dependent manner. The $\mathrm{IC}_{50}$ were calculated on PC3 and HT-29 cells at 48h as being 69.3 and $103.1 \mu \mathrm{g} / \mathrm{ml}$, respectively, for chloroform fraction and $37.1 \mu \mathrm{M}$ and $89.7 \mu \mathrm{M}$, respectively, for taraxasterol (4) (Table 4). Taraxasterol seems to be responsible of the activity of the extract. It is known to possess antiproliferative activity against various cancer cells (Villarreal et al., 1994; Dai et al., 2001).

In conclusion, a new triterpenic diester, 3,21-dipalmitoyloxy-16 $\beta, 21 \alpha$-dihydroxy- $\beta$ amyrine(1), and two natural cyclitols, conduritol C (2) and viburnitol(3), together with four known triterpenes, and seven known flavonoids were isolated from the aerial parts of Chrysanthemum macrocarpum. This study clearly show that the chloroform fraction presents a good activity against Gram-negative bacteria (P. aeruginosa, K. pneumonia, E. coli) with MICs values of $0.5,4$ and $8 \mu \mathrm{g} / \mathrm{ml}$, respectively, better than ampicilline used as control. At these concentrations, no cytotoxic activity was observed on PC3 and HT-29 cells. It can be concluded that this plant may serve as a very good source of potential antibacterial agent and justify their used in traditional medicine as scabicides and for the treatment of intestinal infections. 


\section{Experimental}

\subsection{General experimental procedures}

Optical rotations were measured in $\mathrm{MeOH}$ or $\mathrm{CHCl}_{3}$ with a Perkin-Elmer 241 polarimeter. ${ }^{1} \mathrm{H}$ and ${ }^{13} \mathrm{C}$ NMR spectra were recorded on a BrukerAvance DRX 500 NMR spectrometer $\left({ }^{1} \mathrm{H}\right.$ at $500 \mathrm{MHz}$ and ${ }^{13} \mathrm{C}$ at $\left.125 \mathrm{MHz}\right)$. 2D-NMR experiments were performed using standard Brukermicroprograms. Coupling constants were expressed in $\mathrm{Hz}$, and chemical shifts were given on a $\delta(\mathrm{ppm})$ scale. ESIMS and HR-ESIMS experiments were performed using a Micromass Q-TOF micro instrument (Manchester, UK). The samples were introduced by direct infusion in a solution of $\mathrm{MeOH}$ at a rate of $5 \mu \mathrm{L} \min ^{-1}$. TLC was carried out on precoated silica gel $60 \mathrm{~F}_{254}$ (Merck), and spots were visualized by heating after spraying with $50 \% \mathrm{H}_{2} \mathrm{SO}_{4}$. Kieselgel 60 (63-200 mesh) Merck or LiChroprep RP-18 $(40-63 \mu \mathrm{m})$ Merck silica gel were used for Column chromatography (CC). HPLC was performed on a Dionex apparatus equipped with an ASI-100 autosampler, a P580 pump, a UVD 340S diode array detector, and Chromeleon $^{\circledR}$ software.A prepacked RP-18 column $(201 \mathrm{SP} 510,250 \times 10 \mathrm{~mm}, 5 \mu \mathrm{m}, 90$

Å, Dionex, Vydac, France) was used for semi preparative HPLC of the flavonoids with a binary gradient elution (solvent $\mathrm{A}: \mathrm{H}_{2} \mathrm{O}$ with $0.0025 \%$ TFA, solvent $\mathrm{B}$ : $\mathrm{MeCN}$ ) at 25 ${ }^{\circ} \mathrm{C}$ and a flow rate of $3.5 \mathrm{~mL} \mathrm{~min}{ }^{-1}$; the chromatogram was monitored at 254 and 365 $\mathrm{nm}$. The following reagents were used for cell culture assay: DMEM and foetal calf serum (Gibco BRL, Cergy-Pontoise, France), 3-(4,5-dimethylthiazol-2-yl)-2,5diphenyltetrazolium bromide (MTT), and sodium dodecyl sulfate (SDS) (Sigma Chemical Co., St. Louis, MO).

\subsection{Plant material}


The aerial parts of Chrysanthemum macrocarpum(Sch.Bip.) Coss.\&Kralik ex Batt.were collected in the flowering season from Ghardaia (Algerian septentrionalsahara) in April 2005. The botanical determination was performed by Pr Gérard De Bélair from AnnabaUniversity (Algeria). A voucher specimen has been deposited in the botanic Museum of Angers, France under reference MBAng 2005-8.

\subsection{Extraction and isolation}

Dried and powdered aerial parts (1380 g) of C. macrocarpum were macerated in $20 \%$ aq. $\mathrm{MeOH}(10$ 1). The hydromethanolic extract was concentrated to dryness (under low pressure). The residue was suspended in $\mathrm{H}_{2} \mathrm{O}$ and successively partitioned with $\mathrm{CHCl}_{3}$, EtOAc, and $n-\mathrm{BuOH}(3 \times 300 \mathrm{ml}$, each $)$, respectively, affording a $\mathrm{CHCl}_{3}$ soluble fraction (20 g), an EtOAc-soluble fraction (4 g), and a $n$-BuOH-soluble fraction (20 g). A part (10 g) of the $\mathrm{CHCl}_{3}$ soluble fraction was fractionated by silica gel $\mathrm{CC}$, using a gradient of cyclohexane-EtOAc (1:0 to 0:1) to give 20 fractions. The fraction 6 (964 mg) eluted with cyclohexane-EtOAc (95:5) was fractionated by silica gel CC eluted with a gradient of cyclohexane- $\mathrm{CHCl}_{3} \quad(1: 0 \quad$ to8:2).Fractions $\quad 71-99 \quad(290 \quad \mathrm{mg})$, eluted with cyclohexane- $\mathrm{CHCl}_{3}$ (9:1) were subjected to silica gel $\mathrm{CC}$ using $100 \%$ toluene as solvent, and then fractions 62-75 (141 mg) were further purified by TLC preparative in toluene-acetone $(98: 2)$ to give compound $\mathbf{1}(6.5 \mathrm{mg})$. The fraction $9(680 \mathrm{mg})$ was submitted to silica gel $\mathrm{CC}$ using a gradient of toluene-acetone (1:0 to8:2) to give taraxasterol $4(30 \mathrm{mg})$. Preparative TLC of fractions $36-50(24 \mathrm{mg})$, eluted with toluene-acetone (98:2), developed with a mixture of toluene-acetone (96:4), give taraxasterol 4 (2.3 mg), and calenduladiol-3- $O$-myristate $5(8 \mathrm{mg})$.A part of fraction 12 , eluted with cyclohexane-EtOAc (8:2) was subjected to silica gel vacuum liquid chromatography (VLC)using a gradient of cyclohexane-EtOAc (9:1 to 6:4). Three fractions of $150 \mathrm{ml}$ were collected and monitored by TLC in cyclohexane-EtOAc (8:2). 
Fraction 2 was subjected to silica gel CC using petroleum ether-EtOAc (1:0 to 8:2) to give stigmasterol $6(15 \mathrm{mg})$ and $\beta$-sitosterol7 $(25 \mathrm{mg})$ in pure form.

The EtOAc soluble extract was fractionated by silica gel $\mathrm{CC}$, using a gradient of $\mathrm{CHCl}_{3}-\mathrm{MeOH}$ (1:0 to 0:1). Fractions 7-9 (150 mg), eluted with $\mathrm{CHCl}_{3}-\mathrm{MeOH}$ (95:5) were purified by silica gel CC eluted with EtOAc-MeOH (99:1 to 8:2) to provided apigenin8 (13 mg) and 7-O-methyl-apigenin 9 (10 mg). Fractions 13-16 (491 mg), eluted with $\mathrm{CHCl}_{3}-\mathrm{MeOH}$ (9:1), were fractionated by silica gel $\mathrm{CC}$ using a gradient of EtOAc-MeOH (1:0 to 6:4) to afforded fifteen fractions. Fractions eluted with EtOAc$\mathrm{MeOH}$ (85:15) were submitted to reversed-phase (RP-18) CC, using a gradient of $\mathrm{MeOH}-\mathrm{H}_{2} \mathrm{O}$ (6:4 to 1:0) as eluent, to yield conduritol C 2 (27 mg) and apigenin-7-Oglucoside $10(30 \mathrm{mg})$. The purification of $25 \mathrm{mg}$ of fraction 17, using the same conditions, afforded viburnitol 3 (4.4 mg). Fractions 18-21 (108 mg), eluted with $\mathrm{CHCl}_{3}-\mathrm{MeOH}$ (85:15), were purified by semi-preparative HPLC, using a linear gradient (15 to $20 \% \mathrm{~B}$ during $20 \mathrm{~min}$ ) at $4 \mathrm{ml} / \mathrm{min}$ to give kaempferol-3-O-glucoside $11\left(t_{\mathrm{R}} 9.01\right.$ $\min , 3.5 \mathrm{mg}$ ), kaempferol-7- $O$-glucoside 12 ( $\left.t_{\mathrm{R}} 12.34 \mathrm{~min}, 5.5 \mathrm{mg}\right)$, and luteolin-3'-Oglucoside $13\left(t_{\mathrm{R}} 11.24 \mathrm{~min}, 3.7 \mathrm{mg}\right)$. Fraction $22(25 \mathrm{mg})$ eluted with $\mathrm{CHCl}_{3}-\mathrm{MeOH}$ (8:2), gave 6-C-glucosyl-8-C-arabinosylapigenin $14\left(t_{\mathrm{R}} 20.19 \mathrm{~min}, 7 \mathrm{mg}\right)$, by semipreparative HPLC using a linear gradient (10 to $20 \% \mathrm{~B}$ during $22 \mathrm{~min}$ ) at $4 \mathrm{ml} / \mathrm{min}$.

\subsubsection{Compound 1}

Colourless viscous liquid; ${ }^{1} \mathrm{H}$ and ${ }^{13} \mathrm{C}$ NMR, see Table 1; HRESIMS (positive-ion mode) $m / z: 957.8634[\mathrm{M}+\mathrm{Na}]^{+}\left(\right.$calcd for $\mathrm{C}_{62} \mathrm{H}_{110} \mathrm{O}_{5} \mathrm{Na}$ : 957.8653); ESIMS (positiveion mode) $m / z: 957[\mathrm{M}+\mathrm{Na}]^{+}, 701\left[\mathrm{M}+\mathrm{Na}-\mathrm{C}_{16} \mathrm{H}_{32} \mathrm{O}_{2}\right]^{+}, 685\left[\mathrm{M}+\mathrm{Na}-\mathrm{OH}-\mathrm{C}_{16} \mathrm{H}_{32} \mathrm{O}_{2}\right]^{+}$; $[\alpha]_{\mathrm{D}}^{20}+11.5^{\circ}\left(c 0.76, \mathrm{CHCl}_{3}\right)$.

\subsubsection{Conduritol C (2)}


Colourless crystals; ${ }^{1} \mathrm{H}$ and ${ }^{13} \mathrm{C}$ NMR, see Table 2; ESIMS (positive-ion mode) $\mathrm{m} / \mathrm{z}: 169$ $[\mathrm{M}+\mathrm{Na}]^{+} ;[\alpha]_{\mathrm{D}}^{20} 209.5^{\circ}(c 0.27, \mathrm{MeOH})$.

\subsubsection{Viburnitol (3)}

Colourless crystals; ${ }^{1} \mathrm{H}$ and ${ }^{13} \mathrm{C}$ NMR, see Table 2; ESIMS (positive-ion mode) $\mathrm{m} / z: 187$ $[\mathrm{M}+\mathrm{Na}]^{+}$.

\subsection{Antibacterial activity}

American Type of Culture Collection (ATCC) standard against namely: Staphylococcus aureus (ATCC 25923), Enterococcus faecalis (ATCC 29212) and Gram negative Escherichia coli (ATCC 25922), Pseudomonas aeruginosa (ATCC 27853) and the clinically isolated strain Klebsiella pneumonia were used. The reference strains were obtained from the Pasteur Institute (Algiers). The clinical strain was obtained from the laboratory of bacteriology, Benbadis Hospital, Constantine, using conventional methods (clinical isolation).

\subsubsection{Antibacterial screening}

The disk diffusion assay was used with some modifications (Rasoanaivo and Ratsimamanga, 1992; NCCLS, 1997) to determine the growth inhibition of bacteria by the $\mathrm{CHCl}_{3}$ soluble fraction, EtOAc soluble fraction, $n$ - $\mathrm{BuOH}$ soluble fractionand compounds 4 and 7 of $C$. macrocarpum. The bacteria tested were maintained at $4{ }^{\circ} \mathrm{Con}$ nutrient agar (NA). Base plates were prepared by pouring $10 \mathrm{ml}$ Mueller-Hinton (MH) agar into sterile petri dishes $(9 \mathrm{~cm})$ and allowed to set. Molten $\mathrm{MH}$ agar held at $48{ }^{\circ} \mathrm{C}$ was inoculated with a broth culture $\left(10^{6}-10^{8}\right.$ bacteria per $\left.\mathrm{ml}\right)$ of the test organism and poured over the base plates forming a homogenous top layer. Paper discs (Whatman No. $3,6 \mathrm{~mm}$ diameter) were sterilized by autoclaving. $10 \mu \mathrm{l}$ of the fractions or compounds 4 and $7(128 \mathrm{mg} / 10 \mathrm{ml})$ were applied to paper disc so that each disc contains $128 \mu \mathrm{g}$ of sample. After evaporation of the solvent in a sterile atmosphere, paper discs were placed 
in the top layer of the $\mathrm{MH}$ agar plates. The fractions were tested in triplicate, with ampicillin $\left(10 \mu \mathrm{g} \mathrm{ml}^{-1}\right)$ and ceftazidime $\left(30 \mu \mathrm{g} \mathrm{ml}^{-} 1\right)$ disc as reference. The plates were evaluated after incubation at $37^{\circ} \mathrm{C}$ for $18 \mathrm{~h}$. The results were recorded by measuring the diameter of inhibition zone at the end of 18 hours.

\subsubsection{Thin-layer chromatography-direct bioautography}

Thin-layer chromatography (TLC)-direct bioautographic method (Shai et al., 2008) was applied to identify and localize active compounds in the chloroform fraction against Pseudomonas aeruginosa, Escherichia coli (ATCC 25922), Staphylococcus aureus (ATCC 25923), Enterococcus faecalis (ATCC 29212) and Klebsiella pneumonia. The chloroform fraction or the compounds $\mathbf{4}$ and $\mathbf{7}$ were dissolved in chloroform at a concentration of $1 \mathrm{mg} / \mathrm{ml} .100 \mu \mathrm{l}$ of the chloroform fraction or $50 \mu \mathrm{l}$ of 4 and 7 were spotted at $1 \mathrm{~cm}$ from the base of preparative Merck chromatography silica gel $60 \mathrm{~F}_{254}$ TLC plates. TLC plate loaded with the chloroform fraction and the pure compounds was developed in a hexane: ethyl acetate $(8: 2, \mathrm{v} / \mathrm{v})$ solvent system. After migration, the solvent was evaporated. TLC plates were overlapped homogenously with $10 \mathrm{ml}$ of nutrient agar (Mueller-Hinton) infected by nutrient broth containing bacteria $\left(10^{8} \mathrm{cfu} / \mathrm{ml}\right)$. After solidification of the medium, the TLC plates were incubated for $24 \mathrm{~h}$ at $37{ }^{\circ} \mathrm{C}$. Subsequently, bioautograms developed were sprayed with $2 \mathrm{mg} / \mathrm{ml}$ of $p$ iodonitrotetrazolium bromide (INT) (Sigma). Clear zones on bioautograms indicated inhibition of growth after incubating for $2 \mathrm{~h}$ at $37^{\circ} \mathrm{C}$.

\subsubsection{Determination of the minimums inhibitory concentrations (MICs).}

Tests were performed by the agar dilution method according to the NCCLS with some modifications. The $\mathrm{CHCl}_{3}$ soluble fraction or compounds 4 and 7 were dissolved in ethanol to a final concentration of $512 \mu \mathrm{g} / \mathrm{ml}$. This was serially diluted 2 fold with $\mathrm{MH}$ medium to obtain concentration of $0.5,1,2,4,8,16,32,64$ and $128 \mu \mathrm{g} / \mathrm{ml} .2 \mathrm{ml}$ of each 
concentration was added in Petri dished containing $18 \mathrm{ml}$ of $\mathrm{MH}$ medium previously inoculated with suspension of bacteria $\left(10^{5} \mathrm{CFU} / \mathrm{ml}\right)$ for testing the samples. Control plates contain the culture medium and $2 \%$ of ethanol. Plates were incubated at $37{ }^{\circ} \mathrm{C}$ for 18hours. The minimum inhibitory concentration (MIC) was defined as the concentration at which no colony was observed after incubation. All experiments were performed in triplicates.

\subsection{Cell culture and cell proliferation assay (MTT)}

Human colorectal cell line HT-29 and human prostate carcinoma PC3 cells were purchased from American Type Culture Collection (LGC Standards, Middlesex, UK). Cells were seeded at $3.10^{4} / \mathrm{cm}^{2}$ and grown in DMEM, supplemented with $10 \%$ foetal calf serum, 100 units $/ \mathrm{ml}$ of penicillin, $100 \mathrm{mg} / \mathrm{ml}$ of streptomycin. Cells were incubated under $5 \% \mathrm{CO}_{2}$ humidified atmosphere at $37{ }^{\circ} \mathrm{C}$. Cell viability was determined by the trypan blue dye exclusion method.

The effect of the chloroform fraction of C. macrocarpum and the isolated taraxasterol (4) on cell viability was assessed using the [3-(4,5-dimethylthiazol-2-yl)-2,5diphenyltetrazolium bromide] (MTT) assay, as described previously (Mosmann, 1983). This test is based on the ability of the mitochondrial succinate deshydrogenase enzyme of living cells to reduce MTT to a purple-blue insoluble formazan precipitate. The HT29 and PC3 cells were plated in 96-well plates at concentration of $10^{4}$ cells/well and incubated for $24 \mathrm{~h}$, then treated with various concentrations of chloroform fraction or 4 or ursolic acid used as positive control which were dissolved in dimethyl sulfoxide (DMSO) and diluted with culture medium to give the appropriate final concentrations of 20-140 $\mu \mathrm{g} / \mathrm{ml}$. Controls were done with the same final DMSO concentration in the medium as samples. After incubation of the cells with chloroform fraction for 24 or 48 h or with 4 for 48 hat $37^{\circ} \mathrm{C}, 10 \mu \mathrm{l}$ of $5 \mathrm{mg} / \mathrm{ml}$ MTT solution were added to each well 
and incubated for $4 \mathrm{~h}$ at $37{ }^{\circ} \mathrm{C}$. Then, $100 \mu \mathrm{l}$ of $10 \%$ sodium dodecyl sulfate (SDS) in $0.01 \mathrm{M} \mathrm{HCl}$ was added to each well. The degree of formazan formation, an indicator of living and metabolically active cells, was determined using ELISA reader at $550 \mathrm{~nm}$. Six wells per dose and time point were measured in 3 different experiments.

\section{Acknowledgments}

We wish to thank the Ministry of Higher Education and Scientific Research (Algeria) for financial support. Financial support by CNRS, Conseil Regional Champagne Ardenne, Conseil General de la Marne, Ministry of Higher Education and Research (MESR) and EU-programme FEDER to the PIANET CPER project is gratefully acknowledged. The authors are very grateful to Karen Ple (ICMR) for revising the English.

\section{References}

Balci, M., Sütbeyaz, Y., Secen, H. 1990.Conduritols and related compounds.Tetrahedron, 46: 3715-3742.

Bellakhadar, J., 1997. La pharmacopée marocaine traditionnelle, Ibis Press.

Bennini, B., Chulia, A.J., Kaouadji, M., Thomasson, F., 1992. Flavonoid glycosides from Erica cinerea.Phytochemistry 31, 2483-2486.

Boukef, M.K., 1986. Les plantes dans la médecine traditionnelle tunisienne, Collection: agence de cooperation culturelle et technique.

Boutaghane, N., Kabouche, A., El-Azzouny, A. M., Kabouche, Z., 2008. Composition of the essential oil of Chrysanthemum macrocarpum from Algeria. Chem. Nat. Compounds 44, 817-818. 
Cheon, M.S., Yoon, T., Lee, D.Y., Choi, G., Moon, B.C., Lee, A.-Y., Choo, B.K., Kim, H.K., 2009.Chrysanthemum indicum Linne extract inhibits the inflammatory response by suppressing NF-kappa B and MAPKs activation in lipopolysaccharide-induced RAW 264.7 macrophages. J. Ethnopharmacol. 122, 473-477.

Dai, J., Zhao, C., Zhang, Q., Liu, Z.L., Zheng, R., Yang, L., 2001. Taraxastane-type triterpenoids from Saussurea petrovii. Phytochemistry 58, 1107-1111.

Hiroki, Y., Jan-E, B., 1998. Efficient synthesis of (+), and (-) conduritol C via Palladium (II) catalyzed 1,4-Diacetoxylation in combination with enzymatic hydrolysis.J. Org. Chem.63, 9339-9341.

Jiangsu new medical college, 1993. In: Dictionary of chinesemateria medical science and technology, Shanghai press, pp 2144-2145.

Kim, M.-Y., Kim, Y.-C., Chung, S.-K., 2005. Identification and in vitro biological activities of flavonols in garlic leaf and shoot: inhibition of soybean lipoxygenase and hyaluronidaseactivities and scavenging of free radicals.J. Sci. Food Agric.85, 633-640.

Kindl, H., Hoffmann-Ostenhof, O., 1966.Untersuchungenüber die biosynthese der cyclite-XIII: Vorkommen and biosynthese von cycliten in Asclepiadaceae. Phytochemistry 5, 1091-1102.

Kojima, H., Sato, N., Hatano, A., Ogura, H., 1990. Sterol glucosides from Prunella vulgaris. Phytochemistry 29, 2351-2355.

Krafczyk, N., Kotke, M., Lehnert, N., Glomb, M., 2008. Phenolic composition of rhubarb.Eur. Food Res. Technol. 228, 187-196.

Lee, J.S., Kim, H.J., Lee, Y.S., 2003. A new anti-HIV flavonoid glucuronide from Chrysanthemum morifolium. Planta Med.69, 859-861. 
Lin L.-Z., Harnyl, J.M., 2010. Identification of the phenolic components of Chrysanthemum flower (Chrysanthemum morifolium Ramat). Food chem. 120, 319326.

Mahato, S.B., Kundu, A.P., $1994 .{ }^{13} \mathrm{C}$ NMR spectra of pentacylic triterpenoids. A compilation and some salient features. Phytochemistry 37, 1517-1575.

Matsuda, H., Morikawa, T., Toguchida, I., Harima, S., Yoshikawa, M., 2002. Medicinal flowers VI. Absolute stereostructures of two new flavanone glycosides and a phenylbutanoid glycoside from the flowers of Chrysanthemum indicum L: their inhibitory activities for rat lens aldose reductase. Chem. Pharm. Bull.50, 972-975.

Moiteiro, M., Gaspar, H., Rodrigues, A.I., Lopes, J.F., Carnide, V., 2008. HPLC quantification of dye flavonoids in Reseda luteola L. from Portugal. J. Sep. Sci.31, $3683-3687$.

Mosmann, T., 1983. Rapid colorimetric assay for cellular growth and survival: Application to proliferation and cytotoxicity assays. J. Immunol. Methods65, 55-63.

NCCLS (National Committee for Clinical Laboratory Standards), 1997. Performance standards for antimicrobial disk susceptibility test, 6th ed. Approved standard. M2-A6, Wayne, PA.

Quezel et Santa., 1963. In : La Nouvelle Flore de l'Algérie et des Régions Désertiques Méridionales, Tome II, C.N.R.S. ed,. Paris, pp 982-988.

Rasoanaivo, P., Ratsimamanga-Urveg, S., 1993. In: Monograph of the IFS-NAPRECA Workshop on Bioassays, Antananarivo, Madagascar, pp72-79.

Reynolds, W.F., Sawyer, J.F., Enriquelz, R.G., Escobar, L.I. Chaveez, M.A., Shoolery, J.N., 1985. Total assignment of the ${ }^{13} \mathrm{C}$ spectrum of taraxasteryl acetate by ${ }^{13} \mathrm{C}-{ }^{13} \mathrm{C}$ connectivity experiments and determination of the stereochemistry of taraxasterol by Xray diffraction.Can. J. Chem.63, 1048-1054. 
Shai, L. J., McGaw, L.J., Aderogba, M.A., Mdee, L.K., Eloff, J.N., 2008. Four pentacyclictriterpenoids with antifungal and antibacterial activity fromCurtisiadentata(Burm.f) C.A. Sm. leaves J. Ethnopharmacol. 119, 238-244.

Shi, G.-B., Zhao, M.-H., Zhao, Q.-C., Huang, Y., Chen, Y.-F., 2011. Mechanisms involved in the antinociception of petroleum ether fraction from the EtOH extract of Chrysanthemum indicum in mice.Phytomedicine 18, 609-616.

Singh, B., Dubey, M., 2001.Estimation of triterpenoids from Heliotropium marifolium Koen ex. Retz. in vivo and in vitro. I. Antimicrobial screening. Phytother. Res.15, 231234.

Singh, B., Sahu, P.M., Sharma, M.K., 2002.Anti-inflammatory and antimicrobial activities of triterpenoids from Strobilanthes callosus Nees. Phytomedicine 9, 355-359.

Ukiya, M., Akihisa, T., Yasukawa, K., Kasahara, Y., Kimura, Y., Koike, K., Nikaido, T., Takido, M. 2001.Constituents of Compositae Plants. 2. Triterpenediols, triols, and their 3-O-fatty acid esters from edible Chrysanthemum flower extract and their antiinflammatory effects. J. Agric. Food Chem.49, 3187-3197.

Ukiya, M., Akihisa, T., Tokuda, H., Suzuki, H., Mukainaka, T., Ichiishi, E., Yasukawa, K., Kasahara, Y., Nishino,H. 2002. Constituents of Compositae plants III. Anti tumor promoting effects and cytotoxic activity against human cancer cell lines of triterpene diols and triols from edible Chrysanthemum flowers.Cancer Lett. 177, 7-12.

Villarreal, M.L., Alvarez, L., Alonso, D., Navarro, V., Garcia, P., Delgado, G., 1994. Cytotoxic and antimicrobial screening of selected terpenoids from Asteraceae species.

J. Ethnopharm. 42, 25-29.

Yan, Y.C, Lou, X.E, Jiang, H.D., 1999. Experimental studies on the anti-oxidant effects of water extract from Chrysanthemum indicum. ZhongGuo Xian Dai Ying Yong Yao XueZaZhi16, 16-18. 
Yang, Z.G., Ren, A.N., Xu, L., Sun, X.J., Hua, X.B., 2000. Experimental study on the immunological and anti-inflammatory activities of Chrysanthemum indicum. Chinese journal of traditional Medical science and technology 2, 92-93.

Yoshikawa, M., Morikawa, T., Toguchida, I., Harima, S., Matsuda, H., 2000. Medicinal flowers. II. Inhibitors of nitric oxide production and absolute stereostructures of five new germacrane-type sesquiterpenes, kikkanols $\mathrm{D}, \mathrm{D}$ monoacetate, E, F, and F monoacetate from the flowers of Chrysanthemum indicum L. Chem. Pharm. Bull. 48, $651-656$. 
Table 1. ${ }^{1} \mathrm{H}$ and ${ }^{13} \mathrm{C}$ NMR Spectroscopic Data $\left(\mathrm{CDCl}_{3}\right)$ of compound $\mathbf{1}$

\begin{tabular}{|c|c|c|c|c|c|}
\hline \multicolumn{6}{|c|}{1} \\
\hline position & $\delta_{\mathrm{C}}$ & $\delta_{\mathrm{H}}(\mathrm{J}$ in $\mathrm{Hz})$ & & $\delta \mathrm{C}$ & $\delta_{\mathrm{H}}(J$ in $\mathrm{Hz})$ \\
\hline $\begin{array}{l}1 \mathrm{a} \\
1 \mathrm{~b}\end{array}$ & 38.3 & $\begin{array}{l}1.09, \mathrm{~m} \\
1.65, \mathrm{~m}\end{array}$ & Acyl in & $\mathrm{C}-3$ & \\
\hline $\begin{array}{l}2 \mathrm{a} \\
2 \mathrm{~b}\end{array}$ & 23.6 & $\begin{array}{l}1.66, \mathrm{~m} \\
1.92, \mathrm{~m}\end{array}$ & $1^{\prime}$ & 173.7 & \\
\hline 3 & 80.5 & $4.53, \mathrm{dd}(9.3,5.5)$ & $2^{\prime}$ & 34.9 & $2.32, \mathrm{q}^{\mathrm{t}} \mathrm{d}(7.1,1.0)$ \\
\hline 4 & 37.8 & & $3^{\prime}$ & 25.2 & $1.65, \mathrm{~m}$ \\
\hline 5 & 55.3 & $0.88, \mathrm{~m}$ & $4^{\prime}-13^{\prime}$ & $\begin{array}{l}29.1- \\
29.9\end{array}$ & $1.28, \mathrm{brs}$ \\
\hline $\begin{array}{l}6 \mathrm{a} \\
6 \mathrm{~b}\end{array}$ & 18.2 & $\begin{array}{l}1.44, \mathrm{~m} \\
1.58, \mathrm{~m}\end{array}$ & $14^{\prime}$ & 31.9 & $1.28, \mathrm{~m}$ \\
\hline $\begin{array}{l}7 \mathrm{a} \\
7 \mathrm{~b}\end{array}$ & 32.9 & $\begin{array}{l}1.37, \mathrm{~m} \\
1.56, \mathrm{~m}\end{array}$ & $15^{\prime}$ & 22.7 & $1.32, \mathrm{~m}$ \\
\hline 8 & 39.8 & & $16^{\prime}$ & 14.2 & $0.90, \mathrm{t}(7.4)$ \\
\hline 9 & 46.8 & $1.58, \mathrm{~m}$ & Acyl in & $\mathrm{C}-21$ & \\
\hline 10 & 36.8 & & $1 "$ & 173.3 & \\
\hline 11 & 23.6 & $1.97, \mathrm{~m}$ & $2 "$ & 34.9 & $\begin{array}{l}2.36, \mathrm{q}^{\mathrm{t} d} \\
(7.7,2.7)\end{array}$ \\
\hline 12 & $\begin{array}{l}122 . \\
9\end{array}$ & 5.33, brt (3.5) & $3 "$ & 25.2 & $1.67, \mathrm{~m}$ \\
\hline 13 & $\begin{array}{l}142 . \\
9\end{array}$ & & $\begin{array}{l}4 "- \\
13 "\end{array}$ & $\begin{array}{l}29.1- \\
29.9\end{array}$ & 1.28, brs \\
\hline 14 & 43.9 & & $14^{\prime}$ & 31.9 & $1.28, \mathrm{~m}$ \\
\hline $\begin{array}{l}15 \mathrm{a} \\
15 \mathrm{~b}\end{array}$ & 35.4 & $\begin{array}{l}1.65, \mathrm{~m} \\
1.29, \mathrm{~m}\end{array}$ & $15^{\prime \prime}$ & 22.7 & $1.32, \mathrm{~m}$ \\
\hline 16 & 68.3 & $\begin{array}{l}4.43, \mathrm{dd}(11.7, \\
4.7)\end{array}$ & $16^{\prime \prime}$ & 14.2 & $0.90, \mathrm{t}(7.4)$ \\
\hline 17 & 37.4 & & & & \\
\hline 18 & 48.5 & $\begin{array}{l}2.28, \mathrm{dd}(14.1, \\
4.2)\end{array}$ & & & \\
\hline $\begin{array}{l}19 a \\
19 b\end{array}$ & 42.1 & $\begin{array}{l}1.06, \mathrm{~m} \\
2.11, \mathrm{t}(13.8)\end{array}$ & & & \\
\hline 20 & 34.3 & & & & \\
\hline $\begin{array}{l}21 a \\
21 b\end{array}$ & 76.5 & 4.73 , brt (3.4) & & & \\
\hline $\begin{array}{l}22 a \\
22 b\end{array}$ & 34.1 & $\begin{array}{l}\text { 1. 39, dd (15.7, } \\
3.3) \\
2.17 \text {, dd (15.7, } \\
3.1)\end{array}$ & & & \\
\hline 23 & 28.1 & $0.91, \mathrm{~s}$ & & & \\
\hline 24 & 16.8 & $0.89, \mathrm{~s}$ & & & \\
\hline 25 & 15.6 & $1.00, \mathrm{~s}$ & & & \\
\hline 26 & 16.8 & $1.01, \mathrm{~s}$ & & & \\
\hline 27 & 26.7 & $1.27, \mathrm{~s}$ & & & \\
\hline 28 & 21.4 & $0.81, \mathrm{~s}$ & & & \\
\hline 29 & 27.4 & $0.88, \mathrm{~s}$ & & & \\
\hline 30 & 24.8 & $1.02, \mathrm{~s}$ & & & \\
\hline
\end{tabular}


Table 2. ${ }^{1} \mathrm{H}$ and ${ }^{13} \mathrm{C}$ NMR Spectroscopic Data $\left(\mathrm{CD}_{3} \mathrm{OD}\right)$ of compounds 2-3

\begin{tabular}{|c|c|c|c|c|}
\hline & \multicolumn{3}{|c|}{2} & \multirow{2}{*}{$\begin{array}{l}\mathbf{3} \\
\delta_{\mathrm{H}}(J \text { in } \mathrm{Hz})\end{array}$} \\
\hline & $\delta_{\mathrm{C}}$ & $\delta_{\mathrm{H}}(\mathrm{J}$ in $\mathrm{Hz})$ & $\delta_{\mathrm{C}}$ & \\
\hline 1 & 66.6 & $3.95, \mathrm{~d}(7.5)$ & 69.8 & $\begin{array}{l}3,81, \text { ddd } \\
(14.6,4.8,2.7)\end{array}$ \\
\hline 2 & 71.2 & 3.64 , dd $(10.4,7.7)$ & 75.6 & $3.20, \mathrm{t}(9.3)$ \\
\hline 3 & 72.5 & $3.43, \mathrm{dd}(10.4,4.5)$ & 74.3 & $3.60, \mathrm{t}(9.4)$ \\
\hline 4 & 72.4 & $4.20, \mathrm{t}(4.5)$ & 79.3 & 3. 42, dd $(9.6,3.0)$ \\
\hline 5 & 126.6 & 5.83, ddd $(10.0,4.5,2.0)$ & 69.6 & $4.02, \mathrm{~d}(2.6)$ \\
\hline 6 & 132.4 & $5.75, \mathrm{dd}(10.0,2.0)$ & 37.1 & 1.50, ddd $(10.0,2.0)$ \\
\hline & & & & $2.10 \mathrm{dt}(14.4)$ \\
\hline
\end{tabular}


Table 3. Minimal Inhibitory Concentration (MIC) and Inhibition Zones of $\mathrm{CHCl}_{3}$ fraction and compounds $\mathbf{4}$ and $\mathbf{7}$ from Chrysanthemum macrocarpum against Gram positive and negative bacteria.

\begin{tabular}{|c|c|c|c|c|c|c|c|c|c|c|}
\hline & \multicolumn{3}{|c|}{ Inhibition Zone diameters (mm) } & \multicolumn{3}{c|}{ MIC $(\mu \mathrm{g} / \mathrm{ml})$} \\
\hline Microorganisms & $\begin{array}{c}\mathrm{CHCl}_{3} \\
\text { fraction }\end{array}$ & $\mathbf{4}$ & $\mathbf{7}$ & Ampicilline & Ceftazidime & $\begin{array}{c}\mathrm{CHCl}_{3} \\
\text { fraction }\end{array}$ & $\mathbf{4}$ & $\mathbf{7}$ & Ampicilline & Ceftazidime \\
\hline S. aureus & 24 & 10 & 12 & 30 & & 128 & 128 & 128 & 5 & 16 \\
\hline E. faecalis & 30 & 10 & 10 & 16 & & 128 & 128 & 128 & 10 \\
\hline E. coli & 24 & 18 & - & 18 & & 8 & 32 & $>128$ & 16 \\
\hline P. aeruginosa & 30 & 24 & - & - & 22 & 0.5 & 16 & $>128$ & - & 16 \\
\hline K. pneumoniae & 18 & 12 & - & 14 & & 4 & 32 & $>128$ & 32 \\
\hline
\end{tabular}

-, No inhibition zone 
Table 4. $\mathrm{IC}_{50}$ of $\mathrm{CHCl}_{3}$ fraction of Chrysanthemum macrocarpum and compound $\mathbf{4}$ on the proliferation of human PC3 prostate cancer cells line and human colon cancer HT29 cells line at 24 and $48 \mathrm{~h}$

\begin{tabular}{|c|c|c|c|c|}
\hline \multirow{2}{*}{ Sample } & \multicolumn{2}{|c|}{ PC3 $\left(\mathrm{IC}_{50}, \mu \mathrm{g} / \mathrm{ml}\right)$} & \multicolumn{2}{c|}{ HT-29(IC $50, \mu \mathrm{g} / \mathrm{ml})$} \\
\cline { 2 - 5 } & $24 \mathrm{~h}$ & $48 \mathrm{~h}$ & $24 \mathrm{~h}$ & $48 \mathrm{~h}$ \\
\hline $\mathrm{CHCl}_{3}$ fraction & 80.8 & 69.3 & 122.4 & 103.1 \\
\hline Taraxasterol 4 & $\mathrm{nt}$ & $15.8(37.1 \mu \mathrm{M})$ & $\mathrm{nt}$ & $38.3(89.7 \mu \mathrm{M})$ \\
\hline Ursolic acid & $\mathrm{nt}$ & $25 \mu \mathrm{M}$ & $\mathrm{nt}$ & $25 \mu \mathrm{M}$ \\
\hline
\end{tabular}

$\mathrm{nt}:$ not tested at $24 \mathrm{~h}$ 


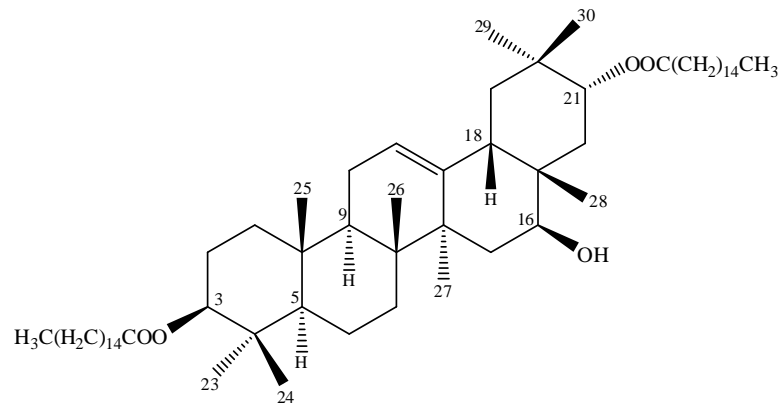

(1)

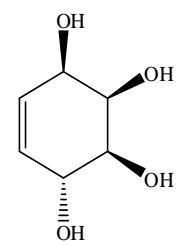

(2)

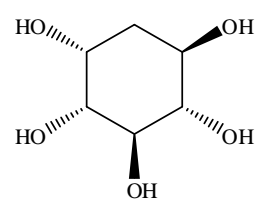

(3)

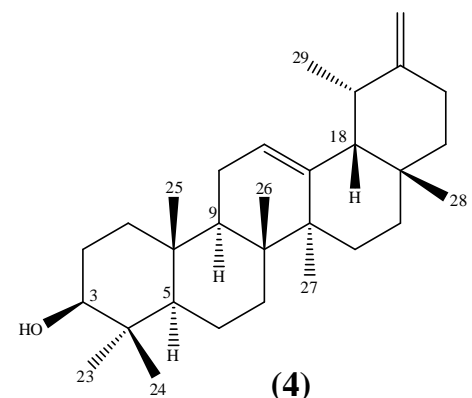

(4)

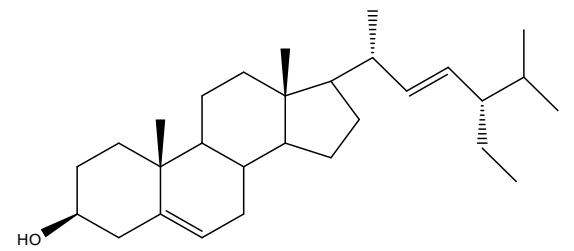

(6)

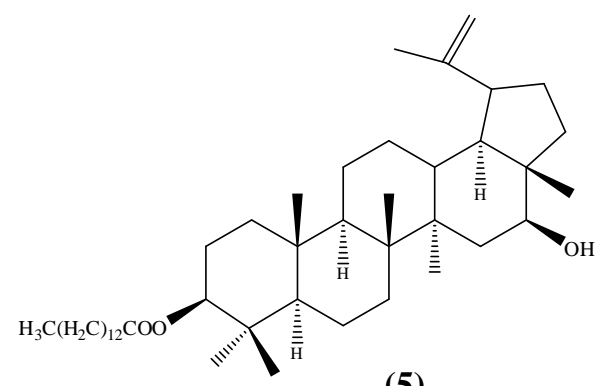

(5)

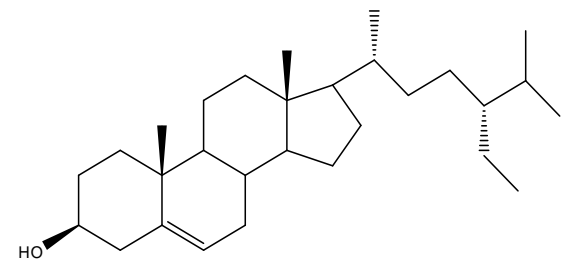

(7)<smiles>Cc1c(O)c([18OH])c(O)c2c(=O)cc(-c3ccc(O)cc3)oc12</smiles><smiles>O=c1c(O)c(-c2ccc(O)cc2)oc2cc(O)cc(O)c12</smiles>

(11) $\mathrm{R}=\mathrm{Glc}, \mathrm{R}^{1}=\mathrm{H}$

(12) $\mathrm{R}=\mathrm{H}, \mathrm{R}^{1}=\mathrm{Glc}$

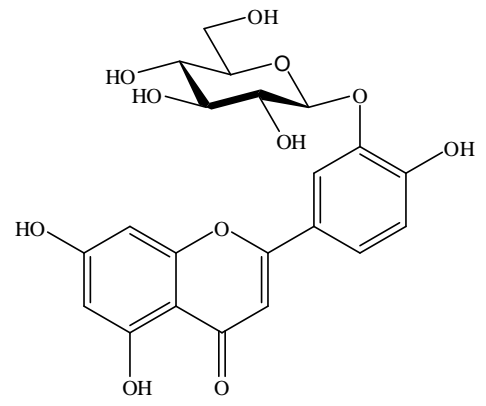

(13)

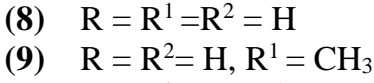

(10) $\mathrm{R}=\mathrm{R}^{2}=\mathrm{H}, \mathrm{R}^{1}=\mathrm{Glc}$

(14) $\mathrm{R}=\mathrm{Ara}, \mathrm{R}^{1}=\mathrm{H}, \mathrm{R}^{2}=\mathrm{Glc}$

Fig. 1. Structures of compounds 1-14 